студентів; розроблення та впровадження моделі формування конкурентоздатності майбутніх електромеханіків у процесі вивчення фахових дисциплін.

\title{
Література
}

1. Андреев В. И. Конкурентология : [учебный курс для творческого развития конкурентоспособности] / В. И. Андреев. - Казань : Центр инновац. технологий, 2004. - 468 с. 2. Бодьян Л. А. Развитие конкурентоспособности студентов технического вуза на основе контекстно-модульного похода: автореф. дис. на соискание ученой степени канд. пед. наук: спец. 13.00.08 «Теория и методика профессионального образования»/ Л. А. Бодьян. - Магнитогорск, 2009. - 22 с. 3. Завацька Л. А. Формування конкурентоспроможності фахівців галузі фізичної культури і спорту у вищих навчальних закладах недержавної форми власності/ Л. А. Завацька, Ж. Г. Сотник, О. С. Ільків // Проблеми фізичного виховання і спорту. 2011. - № 2. - С. 39-44. 4. Максимова О. Г. Система профессиональной ориентации школьников в условиях дифференцированного обучения / О. Г. Максимова // Проспект педагогических идей : сб. науч. трудов/ РАО, НИИ педагогики.Чебоксары, $\quad$ 1997. - С. 63-65. 5. Мезинов В. Н. конкурентоспособности будущего учителя в образовательном процессе университета: автореф. дис. на соискание ученой степени докт. пед. наук: спец. 13.00 .08 «Теория и методика профессионального образования» / В. Н. Мезинов. - Елец, 2009. - 43 с. 6. Менчинская Н. А. Проблемы учения и умственного развития школьника / Н. А. Менчинская. - М. : Педагогика, 1989. - 224 с. 7. Тарасова О. В. Психологічні умови розвитку професійного мислення учнів професійно-технічних навчальних закладів гірничого профілю: дис. ... канд. псих. наук : 19.00.07 / Тарасова Олена Володимирівна. - Київ, 2010. - 176 с. 8. Философский словарь / под ред. И. Т. Фролова. - [5-е изд.] - М. : Политиздат, 1986. - 590 с. 9. Чебышева В. В. Психология трудового обучения / В. В. Чебышева. - М. : Просвещение, 1969. - 303 с.

\section{ПІДГОТОВКА МАЙБУТНЬОГО ВЧИТЕЛЯ ПОЧАТКОВИХ КЛАСІВ ДО ПАТРІОТИЧНОГО ВИХОВАННЯ В УМОВАХ ОНОВЛЕННЯ ПОЧАТКОВОЇ ОСВІТИ}

Філімонова Т. В. Підготовка майбутнього вчителя початкових класів до патріотичного виховання в умовах оновлення початкової освіти.

У статті висвітлено теоретично обгрунтовані питання підготовки майбутніх учителів початкових класів до патріотичного виховання учнів в умовах оновлення початкової освіти. Розглянуто сутність поняття «підготовка майбутніх учителів початкових класів до патріотичного виховання учнів».

Ключові слова: майбутні вчителі, патріотична підготовка, патріотичне виховання, патріотична освіта.

Філімонова Т. В. Подготовка будущего учителя начальных классов к патриотическому воспитанию в условиях обновления начального образования.

В статье освещены теоретически обоснованные вопросы подготовки будущих учителей начальных классов патриотического воспитанию учеников в условиях обновления начального образования. Рассмотрена сущность понятия «подготовка будущих учителей начальных классов к патриотическому воспитанию учеников».

Ключевые слова: будущие учителя, патриотическая подготовка, патриотическое 
воспитание, патриотическое образование.

Filimonova T. V. Preparation of elementary school teacher for patriotic education in conditions of updating primary education.

The article covers theoretically reasonable issues concerning preparing elementary school teachers with regard to patriotic education of pupils in conditions of updating primary education. The article also considers the essence of the concept "preparing elementary school teachers for patriotic education of pupils".

Key words: future teachers, patriotic training, patriotic upbringing, patriotic education.

Провідна роль у формуванні особистості належить учителю, і насамперед, вчителю початкових класів, оскільки саме він закладає фундаментальні основи духовності, освіченості, культури та життєвого досвіду дитини. В умовах модернізації національної системи освіти постала необхідність переосмислити нагромаджену практику підготовки педагогів. Державотворчі процеси, що відбуваються в незалежній Україні протягом останніх десятиліть, зумовлюють необхідність розв'язання проблеми виховання національно свідомих громадян, справжніх патріотів, відданих Вітчизні, готових до плідної праці в ім'я рідного народу.

Патріотичне виховання громадян $\epsilon$ надзвичайно важливим чинником у спрямуванні держави й соціуму до усвідомленого формування активного громадянського суспільства, забезпечення загального сталого розвитку і національної безпеки держави. Ефективність цього процесу залежить від послідовності проведення єдиної політики і скоординованості дій усіх соціальних інститутів, від їх функціональної готовності. Але вагомий внесок у формування та розвиток патріотичної свідомості, виховання в молоді громадянсько-патріотичних якостей мають зробити сучасні освітні заклади [3, с. 46].

Аналіз публікацій 3 проблеми дослідження показав, що першооснови патріотичного виховання були закладені в народній педагогіці, значення якої висвітлюється в роботах О. Любара, В. Мацюка, В. Пугача, М. Стельмаховича, Д. Федоренка. Для нашого дослідження становлять інтерес праці М. Аркаса, Л. Дмитрієва, Д. Лихачова, В. Яременка, у яких висвітлюється виховний ідеал давньоруської епохи, складником якого $є$ патріотичне виховання.

Фундаментальне значення для дослідження проблеми патріотичного виховання школярів, особистості взагалі, має етнопедагогічна спадщина науковців, діячів культури, педагогів, письменників України: М. Драгоманова, М. Коцюбинського, Лесі Українки, І. Франка, Т. Шевченка тощо.

3-поміж класиків педагогічної науки до проблем патріотизму зверталися Г. Ващенко, О. Духнович, А. Макаренко, О. Огієнко, С. Русова, Г. Сковорода, В. Сухомлинський, К. Ушинський, Я. Чепіга та інші видатні науковці. У своїх працях і наукових розробках вони висвітлювали актуальні для свого часу проблеми розвитку патріотичних почуттів школярів як складника національної системи виховання, висували ідею виховання «свідомого» громадянина, патріота своєї Батьківщини [2, с. 65].

Проблемі патріотичного виховання, сутності таких понять, як «патріотична свідомість», «любов до Батьківщини», присвячені фундаментальні праці науковцівфілософів В. Бичка, О. Забужко, І. Надільного, І. Стогнія, В. Шинкарука та ін. Для нашого дослідження цінними $є$ роботи сучасних психологів: I. Беха, А. Богуш, М. Боришевського, В. Котирло, Ю. Трофімова, О. Чебикіна та інших, які в своїх наукових працях досліджують поняття «патріотизм». 
Важливу допомогу у процесі теоретичного усвідомлення нових тенденцій у вітчизняній педагогічній науці надало вивчення робіт О. Вишневського, О. Губко, Є. Зеленова, П. Кононенка, В. Кузя, Ю. Руденка, В. Сипченка, М. Стельмаховича, Б. Ступарика, Б. Чижевського, К. Чорної, Г. Шевченко, Л. Штефан, П. Щербаня, які основою патріотичного виховання вважають національну свідомість та наголошують на усвідомленні безперечної цінності Батьківщини.

Meта статmi полягає у висвітленні підготовки майбутніх учителів початкових класів до патріотичного виховання учнів в умовах оновлення початкової освіти.

Сучасна початкова школа характеризується системними змінами у структурі та змісті навчального процесу, що зумовлює необхідність підготовки вчителя нової формації як професіонала й людини культури, здатного до формування, розширення та збагачення досвіду дитини. На державному рівні проблеми підготовки вчителів відображені в законах України «Про освіту», «Про вищу освіту», Державній національній програмі «Освіта» (Україна XXI століття), Національній доктрині розвитку освіти, Державній програмі «Вчитель», Галузевий стандарт підготовки бакалавра педагогічної освіти та ін.

Державним стандартом початкової загальної освіти передбачена освітня галузь «Людина і світ», передбачає усвідомлення школярами своєї належності до природи і суспільства, створення елементарної бази для засвоєння учнями відповідно до вікових особливостей різних видів соціального досвіду, системи цінностей суспільства, морально-правових норм, традицій. Розвиваючий аспект змісту цієї освітньої галузі передбачає формування досвід творчої діяльності учнів, оволодіння узагальненими способами дій, рольове моделювання способів поведінки в різних ситуаціях, розвиток активного пізнавального ставлення до дійсності.

Найважливішим виховним аспектом цієї освітньої галузі $\epsilon$ формування у школярів патріотизму, поваги до Української держави, іiї символіки, свідомого бажання зробити свій внесок у становлення України як демократичної заможної держави - рівноправного члена світової спільноти [1, с. 31]. Виховне спрямування забезпечується набуттям учнями досвіду емоційно-ціннісного ставлення до навколишнього світу через вибір змісту, особистісно значущого для дітей, його зв'язок $з$ навколишньою дійсністю, співвідношення системи потреб і мотивів, створення умов для самовираження учнів у різних видах діяльності.

Багатоплановий зміст освітньої галузі посилює спрямованість навчального плану початкової школи на всебічний розвиток особистості, надає змогу створити передумови для цілісної системи навчання та педагогічних впливів. Освітня галузь «Людина і світ» у початковому періоді враховує наступність у зв'язках між дошкільною, початковою загальною та базовою загальною середньою освітою й окреслюється змістовими лініями: людина як особистість, людина серед людей, людина, природа і суспільство, культура, нежива природа, жива природа, планета Земля, рідний край, наша Батьківщина - Україна.

Успішне становлення Української держави неможливе без відродження та розвитку національної системи освіти і виховання, без формування у підростаючого покоління високого рівня духовності й патріотизму. Формування громадянинапатріота можливе не лише на основі створення необхідних зовнішніх, об'єктивних виховних умов, але й з урахуванням індивідуальних, вікових особливостей дітей та молоді, їхньої здатності до прийняття патріотичних ідей, національних цінностей, прагнень до розбудови держави.

Усім відома істина - діти початкових класів люблять учитись, але часто забувають: діти люблять учитись добре! I тому головне завдання вчителя - створити 
умови, що забезпечують дитині успіх у навчанні, відчуття радості від того, що я «знаю», я «вмію». Не слід забувати слова В. Сухомлинського: «Є успіх, є бажання вчитися. Особливо важливо це на першому етапі навчання - в початковій школі, де дитина не вміє долати труднощів, де невдача приносить справжнє горе». А. Соловейчик говорив: «...вдумайтеся в те, як ви взаємодієте 3 дитиною, і як вона сприймає вас i ваші уроки, педагогіка повинна бути педагогікою співробітництва» [4, с. 83].

Видатний педагог В. Сухомлинський створив оригінальну педагогічну систему, що грунтується на принципах гуманізму, на визнанні особи дитини вищою цінністю, на яку повинні бути орієнтовані процеси виховання й освіти, творча діяльність згуртованого колективу педагогів-однодумців і учнів. Він будував процес навчання як радісну працю. Шалва Амонашвілі у своїх книгах «Здравствуйте, дети!», «Как живете, дети?», «Единство цели» формулює прості принципи своєї педагогіки: любити дитину, олюднити середовище, в якому живе дитина, прожити в дитині своє дитинство. Навчання без виховання не буває, а виховувати, за висловом Ш. Амонашвілі, можна тільки тоді, «коли виникає духовна спільність між учителем й учнем». Світогляд учителя, який обрав для себе гуманну педагогіку, передбачає активний моральний вибір добра, безмежну віру в Дитину, у спорідненість душ учителя й учня, у єдність «морального закону всередині нас».

Сучасні перетворення в сучасному українському суспільстві зумовили нагальну потребу в компетентних громадянах. Відповідно, основу формування ключових компетентностей особистості повинна закласти сучасна школа. Нині школа повинна навчити учня вчитися, планувати свою працю, вчитися самостійно, самому шукати шляхи власного розвитку. Йдеться не про те, щоб начинити школяра новими даними про новітні відкриття й забезпечити науковий підхід до змісту освіти, а насамперед про розвиток навичок самостійності навчання, здатності до самоорганізації і планування часу, відповідальності, комунікабельності, уміння працювати в команді якості, що майже не розвинені в наших дітей.

Патріотизм виявляється у практичній діяльності, спрямованій на всебічний розвиток своєї країни, захист іiі інтересів. Патріотизм - соціально-історичне явище. Елементи його виникли як усвідомлення родових зв'язків, обрядів, звичаїв. Слово «патріотизм» (від «patris») - грецького походження, в перекладі означає «батьківщина, вітчизна». Уперше воно з'явилося в період Великої Французької революції (1789-1793р.). Патріотами називали себе борці за народ, захисники республіки.

У філософському словнику патріотичне виховання розглядається як виховання, змістом якого $є$ любов до Вітчизни, відданість, гордість за ії минуле й сучасне прагнення захищати інтереси Батьківщини. Це визначення актуалізує роль патріотичного виховання, оскільки саме через активну діяльність людини на користь суспільства виявляються її справжні почуття.

Важливим завданням виховання в українській школі $є$ також подолання в учнів недовіри й підозрілості у ставленні до інших народів і націй, сприяння толерантності міжнаціональних взаємовідносин в умовах багатонаціональної держави [2, с. 46].

У контексті підготовки майбутнього вчителя заслуговує на увагу дослідження С. Русскова, в якому виокремлено загальні та спеціальні педагогічні умови професійної підготовки виховання учнів. Вони забезпечують ефективне рішення завдань підготовки майбутнього вчителя початкових класів. Отже, до загальних педагогічних умов відносяться педагогічні обставини, необхідні і достатні задля нормального функціювання педагогічного процесу у вищій школі незалежно від 
профілю підготовки фахівця [6, с. 58].

Під загальними умовами дослідник розуміє:

- загальну мету підготовки фахівця;

- зміст загальної підготовки;

- наявність певної системи підготовки;

- педагогічні принципи;

- загальні педагогічні форми і методи підготовки фахівців у ВНЗ;

- формування у майбутніх учителів нового педагогічного мислення;

- морально-психологічний клімат;

- матеріально-технічна база, ТЗН;

- наявність творчо працюючих фахівців.

До спеціальних педагогічних умов С. Руссков відносить необхідні і достатні умови, що забезпечують підготовку вчителя до професійно-творчої діяльності у виховання молодших школярів. Наприклад, власну мету і завдання; зміст, зумовлений власною метою і завданнями; урахування місцевих і регіональних особливостей при визначенні змісту підготовки; урахування «місцевих потреб» у фахівцях; використання нетрадиційних форм і методів підготовки; урахування мотиваційної спрямованості; наявність спеціальної матеріально-технічної бази (музей, періодична художня виставка, експонати тощо).

\section{Література}

1. Даль В. И. Толковый словарь живого великорусского языка / В. И. Даль. - М., 1955. 2. Педагогический энциклопедический словарь / гл. ред. Б. М. Бим-Бад. - М. : Большая Российская энциклопедия, 2003. 3. Селевко Г. К. Энциклопедия образовательных технологий: в 2 т. / Г. К. Селевко. - М. : НИИ школьных технологий, 2006. - Т. 2. - 816 с. 4. Теория воспитания. Лабораторно-практические занятия для студентов: [учеб. пособ.]/ под ред. И. А. Тютьковой. - М. : «РИО» Мособлупрполиграфиздата, 2000. - 173 с. $\quad$ 5. Ушинский К. Д. Избранные педагогические сочинения: в 2 т. / К. Д.Ушинський. - М., 1974. б. Харламов И. Ф. Педагогика: [учеб. пособ.] / И. Ф. Харламов. - М. : Высш. шк., 1999. - 512 с.

Олег Цись

\section{АНАЛІЗ СУЧАСНИХ ПІДХОДІВ ДО ФОРМУВАННЯ ПРОФЕСІЙНОЇ МОБІЛЬНОСТІ МАЙБУТНІХ ФАХІВЦІВ}

Цись О. О. Аналіз сучасних підходів до формування професійної мобільності майбутніх фахівців.

У статті автор розкриває різні підходи (системний, особистісно-орієнований, суб'єктно-діяльнісний) до формування професійної мобільності майбутніх фахівців. Викладені результати теоретичного аналізу науково-педагогічної літератури, пов'язаної з підходами до формуванням професійної мобільності майбутніх фахівців. Окреслено шляхи і напрями задля подальших досліджень.

Ключові слова: професійна мобільність, формування професійної мобільності, системний підхід, особистісно-орієнований підхід, суб'єктно-діяльнісний підхід.

Цысь О. А. Анализ современных подходов к формированию профессиональной мобильности будущих специалистов.

В статье автор раскрывает различные подходы (личностно-ориентирований, 